\title{
MULTIMEDIA, HYPERTEXT AND HYPERMEDIA TEACHING AIDS - A CURRENT TREND IN EDUCATION
}

\section{Jiři DOSTÁL}

\begin{abstract}
The article deals with the use of multimedia, hypertext and hypermedia teaching aids in current education. This new technology plays an essential role in teaching and learning nowadays. Modern electronic teaching aids can help individuals acquire new knowledge; they can also encourage learners to self-test, self-question, and self-regulate learning while looking for solution to didactic problems.
\end{abstract}

Key words: education, teaching, multimedia, hypertext, hypermedia, multimedia teaching aids, hypermedia teaching aids, educational animation, e-learning, e-Book, e-textbook, MS PowerPoint, multimedia literacy.

\section{MULTIMEDIÁLNÍ, HYPERTEXTOVÉ A HYPERMEDIÁLNÍ UČEBNÍ POMŮCKY - TREND SOUDOBÉHO VZDĚLÁVÁNÍ}

Resumé: Článek pojednává o využívání multimediálních, hypertextových a hypermediálních učebních pomi̊ckách v soudobém vzdělávání. Tyto nové technologie hrají podstatnou roli v dnešní výuce a procesu učení. Moderní elektronické učebni pomůcky mohou žákům pomoci získat nové znalosti, mohou také povzbuzovat žáky k testování, seberegulaci a samostatnému učení, zatím co oni hledají rešení didaktických problémů.

Klíčová slova: vzdělávání, vyučování, multimédium, hypertext, hypermédium, multimediální učební pomůcka, hypermediální učební pomůcka, výuková animace, e-learning, elektronická kniha, elektronická učebnice, MS PowerPoint, multimediální gramotnost.

\section{Úvod}

Komunikace je s člověkem spjata od samého počátku a realizuje se prostřednictvím řady médií. Jak uvádí P. Sak (1), lze rozlišovat čtyři etapy existence médií v lidské civilizaci, přičemž současná etapa je charakteristická využíváním počítače a internetu a propojováním jednotlivých médií $\mathrm{v}$ technologii multimédií za použití digitalizace.

Vývoj v oblasti komunikace a komunikačních médií se zákonitě odehrává i ve vzdělávání, které je podstatnou součástí lidské existence. Tradiční slovní komunikace vedená mezi vzdělávajícím (pedagog, učitel, vychovatel...) a vzdělávaným (či vzdělávanými) byla s postupem času doplňována o další média a technologie - kresba, hliněné tabulky, papirus a později papír, tabule pro psaní křídou, knihtisk (mohly tak vzniknout tištěné učebnice), pomůcky na bázi fólií pro zpětný projektor, výukový film, didaktický počítačový program, elektronická výuková prezentace, vzdělávací internetový portál, e-learningový systém, e-beam, interaktivní tabule atd. Soudobé vzdělávání je celosvětově charakteristické postupným zaváděním multimediálních, hypertextových a hypermediálních učebních pomůcek do výuky.

\section{Význam učebních pomůcek}

Každý z pedagogů se s učebními pomůckami denně setkává, at’ už jako uživatel anebo přímo jejich tvůrce. Při aplikaci je nutné věnovat náležitou pozornost jejich vhodnému zakomponování do vzdělávacího procesu, jelikož pouze při správném metodickém využívání umožňují efektivněji dosahovat vzdělávacích cílů. Avšak to, že má pedagog učební pomůcky $\mathrm{k}$ dispozici, ještě neznamená, že budou pro osvojování vědomostí, dovedností a postojů př́nosem. Naopak, jejich nevhodné využití může působit kontraproduktivně. Pro seznámení s obecnými principy využívání učebních pomůcek, s čímž úzce souvisí i uplatňování zásady názornosti, odkazujeme čtenáře na publikaci (2).

Učební pomůcky jsou veškeré přirozené objekty nebo předměty napodobující skutečnost nebo symboly, které ve vyučování a učení přispívají jako zdroje informací k vytváření, prohlubování a obohacování představ a umožňují 
vytvářet dovednosti v praktických činnostech žáků, slouží k zobecňování a osvojování zákonitostí přírodních a společenských jevů. Používají se především proto, aby se vytvořily podmínky pro intenzivnější vnímání učební látky, aby do celkového procesu bylo zapojeno co nejvíce receptorů, především zrakových a sluchových (3). Jinak řečeno, učební pomůcky jsou předměty zprostředkující nebo napodobující realitu, napomáhající větší názornosti nebo usnadňující výuku (4).

\section{Multimediální učební pomůcky}

S nástupem počítačů a rozvojem jejich využívání ve vzdělávání se stále více setkáváme s pojmem multimediální učební pomi̊cka. Multimediální učební pomůcky jsou pro vzdělávání významné, jelikož obsahují informace vyjádřené formami, které účinně působí na smysly učícího se jedince, čímž je vhodně naplňována zásada názornosti. Tím, že je prostřednictvím multimédií působeno souběžně na více smyslových receptorů $\mathrm{v}$ jednom okamžiku, dosahujeme lepších výsledků výuky, učivo je trvaleji a hlouběji osvojeno.

Obecně lze multimédium chápat jako digitální prostředek integrující různé formáty dokumentů, resp. dat (napřr. text, tabulky, animace, obrazy, fotografie, schémata, ilustrace, grafy, mapy, zvuk, mluvený komentár̆, video apod.). Jak uvádí J. Pavlovkin (5), významným znakem je interaktivita, která odlišuje multimediální dílo od klasického audiovizuálního díla (např. film) či dokumentu, který jen kombinuje text s tabulkami, grafy a obrázky (je jedno, zda se jedná o tištěný anebo elektronický dokument).

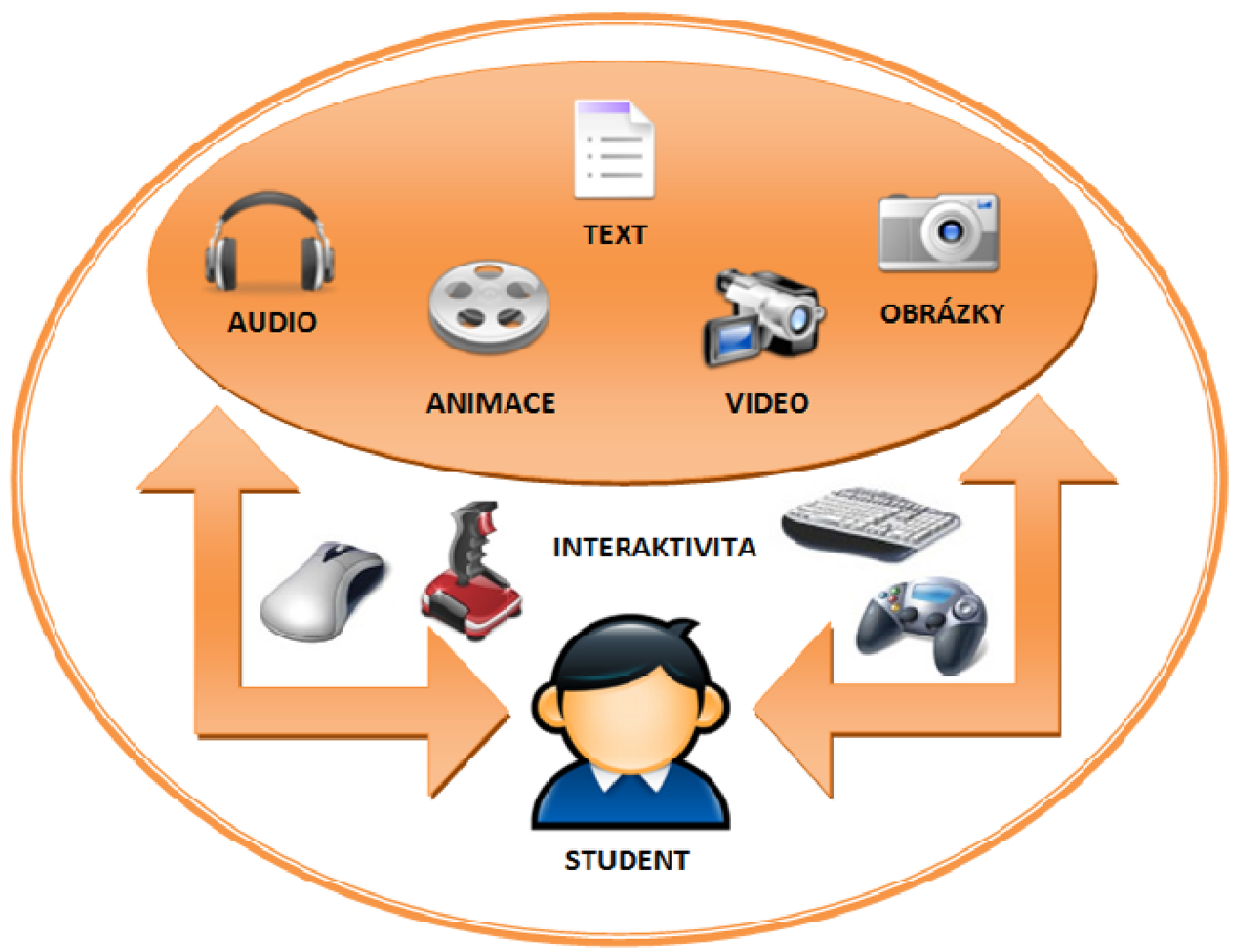

Obr. č. 1: Multimediální učební pomůcka ve vztahu ke studentovi.

Interaktivita umožňuje oboustrannou komunikaci (učící se vs. multimediální učební pomůcka) a student tak má možnost prostřednictvím uživatelského rozhranní aktivně zasahovat do chodu programu a ne jen pasivně percipovat jeho obsah. Ke svému chodu (k tomu, aby mohlo docházet $\mathrm{k}$ interakci uživatele) vyžadují multimédia zpravidla techniku - většinou se jedná o multimediální počítač s př́ślušnými periferními zařízeními.

Mezi často využívané multimediální učební pomůcky lze zařadit např. výukový software, didaktické počítačové hry nebo multimediální výukové prezentace. Pokud jsou využívána multimédia př̀i učení, hovoříme o tzv. multimediálním učení (6), avšak nejen $\mathrm{v}$ tomto 
případě. Pro realizaci multimediálního učení je nepodstatné, zda do procesu učení vstupují multimédia (v podobě integrovaných interaktivních učebních pomůcek) anebo jednotlivé pomůcky různých formátů (jednotlivá média), které umožňují prezentovat informace (text, obraz, video, zvuk...) působící na smysly člověka současně. Myšlenka multimediálního působení ve výuce však není nová a nebádal k němu již J. A. Komenský: „Proto budiž učitelüm zlatým pravidlem, aby všecko bylo předváděno smyslům, kolika možno. Tudiž věci viditelné zraku, slyšitelné sluchu, vonné čichu, chutnatelné chuti a hmatatelné hmatu; a může-li něco býti vnímáno najednou více smysly, budiž to predvádéno více smyslům,..." (7).

Jelikož se nepodařilo v žádné z obdobně zaměřených prací $(8,9,10,11,12,13,14,15,16$, $17,18)$ najít definici multimediální učební pomůcky, byla vytvořena následující definice:

\section{Multimediální učební pomůcka je digitální prostředek integrujicí různé formáty dokumentů, resp. dat (např. text, tabulky, animace, obrazy, zvuk, video apod.), zprostřed- kující nebo napodobující realitu, napomáhající větši názornosti nebo usnadňujicí výuku.}

\section{Hypertextové a hypermediální učební pomůcky}

Každý z nás si dokáže představit klasickou tišsěnou knihu, kterou P. Sak (1) charakterizuje jako přehledně uspořádaný, lineární, kontinuální, hierarchizovaný a ukončený text. S nástupem počítačů se však klasický text z tištěné knihy přesunul na monitor počítače, PDA či e-Book reader (ke čtení speciálně uzpůsobené zařízení). I nadále však zůstalo společným dorozumívacím prostředkem písmo, které je zobrazováno monitorem či displejem. Písmo zachycené v elektronické podobě lze snadno upravovat, kopírovat a tisknout, naopak digitalizace tištěného písma již tak snadná není.

Mezi čtenáři existují výhradní zastánci čtení tradičních knih, kteří ty elektronické striktně zavrhují, vedle toho se však postupně objevují čtenárí elektronických knih. Za účelem snadného šîrení elektronických knih jsou na internetu zakládány $\mathrm{k}$ tomu určené servery, např. $(19,20$, 21), Google vytvořil speciální vyhledávací nástroj Google Book Search (22).

Velkou nevýhodou tištěných knih je určitá omezenost toho, kolik jich v daném okamžiku můžeme mít při sobě (problémem je hmotnost a rozměry). U elektronických knih jsme pouze limitováni kapacitou dostupné paměti pro jejich uložení, avšak je bezpodmínečně nutné mít $\mathrm{k}$ dispozici čtecí zařízení s př́íslušným softwarem.

Jedním z typů tištěných knih vytvářených pro vzdělávací účely jsou učebnice (o tradičních učebnicích pojednává podrobněji např. publikace J. Průchy (23)). Jsou specifické tím, že mají obsah a strukturu uzpůsobenu k didaktické komunikaci. S tím, jak se ICT stále více a více včleňují do vzdělávání, se začínají objevovat elektronické učebnice (lze užívat i zkrácený termín $\boldsymbol{e}$-učebnice, v zahraničí se setkáváme s termínem e-textbook), kterými je zde myšlen druh elektronické publikace uzpuosobené svým obsahem a strukturou $k$ didaktické komunikaci.

Z teorie učení vyplývá, že čím intenzivněji učící se jedinec s učebním textem pracuje, tím efektivnější učení je. V tištěném textu je možné důležité pasáže zvýrazňovat a podtrhávat, na okraje je možné vpisovat excerpty, zachycovat přeformulované myšlenky, navíc je možné se k takto osobitým zpo̊sobem upravenému materiálu kdykoliv vracet. O tyto možnosti jsou elektronické učebnice (zatím) ochuzeny. Pokud by byla klasická tištěná učebnice pouze převedena do elektronické podoby (např. formát PDF) se všemi jejími charakteristikami a byla tak zachována lineárnost, kontinuálnost a ukončenost textu, př́liš̌ efektivní učení by nenabízela - nelze s ní pracovat jinak, než že budeme text stránku po stránce posouvat na monitoru. Zkušenosti naznačují, že řada učících se jedinců si raději obsah takového elektronické učebnice vytiskne (př́padně i jednotlivé listy sváže) a poté studuje tradičním způsobem.

Přitažlivost elektronického textu pro učícího se lze zvýšit jeho transformací do hypertextové podoby ${ }^{1}$, kdy se stává text interaktivním. Pokud se jedná o transformaci prostého textu, hovoříme o hypertextových učebních pomi̊ckách, pokud o transformaci textu s obrázky, tabulkami a grafy, který může být navíc obohacen o animace, video a zvuky, hovoříme o hypermediálních ${ }^{2}$ učebních pomůckách.

Charakter hypertextu vyplývá z jeho virtuální povahy - oproti tištěnému textu skladovanému ve

\footnotetext{
${ }^{1}$ Hypertext je text složený z lexií (bloků slov nebo symbolů), elektronicky propojených cestami (elektronické linky) v otevřené a stále neukončené struktuře (síti) textů (24).

${ }^{2}$ Hypermédium je digitální prostředek, který obsahuje aktivní odkazy nejen na texty, ale i tabulky, animace, obrazy, zvuk, video apod. (25).
} 
formě fyzických znaků na fyzickém povrchu je uchováván v elektronických, nehmotných kódech, které jsou umístěny $\mathrm{v}$ paměti počítače nebo $\mathrm{v}$ sít'ových systémech. V obecné rovině z povahy hypertextu jakožto média vyplývá, že v něm neexistuje centrální, hlavní text, kterému jsou jiné texty podřazeny tak, jak je tomu v prostorové koncepci tištěné stránky.



Obr. č. 2: Hypermediální učební pomůcka ve vztahu ke studentovi. 
U hypertextových učebních pomůcek je však zpravidla zrrejmé, který text je hlavní, kde má učící se jedinec s jeho osvojováním začít (je jedno, zda je hypertextový obsah umístěn na $\mathrm{CD}$ a nebo on-line na webu). Ostatní texty však mohou být bez jakékoliv hierarchické struktury. Autor (pedagog) nemůže bez vnějších instrukcí určit, $v$ jakém pořádku bude studující jeho text číst, a pokud je sdílen on-line, ani s jakým dalším dokumentem bude propojen (jaký další odkaz na něj bude směřovat). Způsob studia představuje základní odlišnost klasického textu od hypertextu, který předpokládá multisekvenční čtení (24). V hypertextu čtenář (žák, student) označuje kurzorem link (nejčastěji podtržený a podsvícený text), který nese metaobsah (hypertextovou adresu jiného dokumentu), aktivuje jej a na obrazovce se objeví obsah odkazovaného materiálu.

Jak uvádí Sak a kol. (1), přechod k četbě multimediálního hypertextu probíhá především u skupiny mládeže ve věku vysokoškolských studentů.

Jelikož se nepodařilo $\mathrm{v}$ literatư̌re nalézt žádnou definici hypermediální učební pomůcky, předkládáme k diskuzi následující:

Hypermediální učební pomůcka je digitální prostředek, který obsahuje aktivní odkazy nejen na texty, ale i tabulky, animace, obrazy, zvuk, video apod., zprostředkující nebo napodobujicí realitu, napomáhajicí větší názornosti nebo usnadn̆ující výuku.

\section{Tvorba multimediálních, hypertextových a hypermediálních učebních pomůcek}

Vytváření multimediálních, hypertextových a hypermediálních učebních pomůcek není jednoduchou záležitostí a zpravidla je poté nutné provádět jejich evaluaci. Uvedené učební pomůcky mohou být vytvářeny na různé úrovni náročnosti a složitosti. Mezi ty méně náročné patří např. tvorba „PowerPointových“3 výukových prezentací, kdy si sám pedagog nejdříve rozvrhne strukturu vytvářené učební pomůcky a poté zpracovává obsah (nejen v podobě didaktického textu, ale i didaktického obrazu, zvuků, animací, grafů, schémat atp.).

\footnotetext{
3 Nejčastěji je využíván k tvorbě multimediálních výukových prezentací program MS PowerPoint, avšak lze využít i program Impress OpenOffice.org, Freelance Graphics, Charisma, MagicPoint, KPresenter, Adobe Persuasion či jiné.
}

Obdobně je tomu u prezentačního software, který je dodáván spolu s interaktivními tabulemi. O zkušenostech ve svých článcích referují např. I. Dömischová (26) a N. Babić S. Irović (27). Zkušenější uživatelé $\mathrm{z}$ řad pedagogů mohou pro tvorbu využít i některý z editorů webových stránek a vytvářet tak učební pomůcky v této podobě.

Složitější projekty předpokládají realizační tým, který se skládá nejen z pedagogů, kteří vytvářejí vlastní didakticky transformovaný obsah, ale i grafiků, animátorů, fotografů, kameramanů (28), programátorů a příp. jiných profesí. Výsledky takových projektů jsou multimediální elektronické učebnice, sety e-learningových učebních pomůcek, multimediální výukový software, aj.

\section{Závěr}

Na závěr si dovolím položit jednu otázku. Je vůbec možné $\mathrm{v}$ době informační společnosti vzdělávat bez informačních technologií? Domnívám se, že ne, a právě i proto se využívání multimediálních, hypertextových a hyper-mediálních učebních pomůcek jeví jako velmi vhodné, zejména s ohledem na rozvoj multimediální (31) a internetové

gramotnosti vzdělávaných.

\section{Literatura}

(1) SAK, P. - MAREŠ, J. - NOVÁ, H et all. Člověk a vzdělávání v informační společnosti. Praha : Portál, 2007. 290 s. ISBN 978-80-7367230-0.

(2) DOSTÁL, J. Učební pomi̊cky a zásada názornosti. Olomouc : Votobia, 2008. $40 \mathrm{~s}$. ISBN 978-80-7220-310-9. Dostupné na http://sites. google.com/site/dos003/.

(3) KUJAL, B. a kol. Pedagogický slovník. 2. díl. Praha : SPN, 1967. $533 \mathrm{~s}$.

(4) PRŮCHA, J. a kol. Pedagogický slovník. Praha : Portál, 2004. 322 s. ISBN 80-7178-772-8.

(5) PAVLOVKIN, J. Multimédiá - významná podpora didaktických procesov pedagoga a edukantov. In Technika - informatyka edukacja. Rzeszow : Uniwersytet Rzeszowski, 2007. s. 146 - 151. ISBN 978-83-88845-91-8.

(6) MAYER, R. E. Multi-media learning. Cambridge : Cambridge University Press. 2001. 210 p. ISBN 0-521-78749-1.

(7) KOMENSKÝ, J. A. Velká didaktika. In Vybrané spisy Jana Ámose Komenského. Svazek I. Redakce Jan Patočka. 1. vyd. Praha: SPN, 1958. s. $41-281$. 
(8) WALAT, W. Od podrecznika konwencjonalnego do multimedialnego (elektronicznego). In Technika - informatyka edukacja. Rzeszow : Uniwersytet Rzeszowski, 2005. s. 215 - 229. ISBN 83-88845-56-X.

(9) HEDE, A. Integrated Model of Multimedia Effects on Learning. Journal of Educational Multimedia and Hypermedia. Volume 11, Issue 2, 2002. Norfolk, AACE. p. 177-191. ISSN $1055-8896$.

(10) PIECUCH, A. Multimedia w praktice szkolnej. In Trendy technického vzdélávání. Olomouc : Votobia, 2008. s. 428 - 432. ISBN 978-80-7220-311-6.

(11) CHROMÝ, J. K pojmu multimédia. In Modernizace vysokoškolské výuky technických předmětů. Hradec Králové : Gaudeamus, 2006. s. 72 - 75. ISBN 80-7041-835-4.

(12) MAYER, R. E. The Cambridge Handbook of Multimedia Learning. Cambridge : University Press, 2005. 663 p. ISBN 9780521838733

(13) CHUDÝ, Š. Některé aspekty využití multimédií při výuce. In Trendy technického vzdélávání. Olomouc : Votobia, 2005. s 305 308. ISBN 978-80-7220-227-8.

(14) NAJJAR, L. J. Multimedia Information and Learning. Journal of Educational Multimedia and Hypermedia. Volume 5, Number 2, 1996. p. 129 - 50. ISSN 1055-8896.

(16) WALAT, W. Multi- i hipermedialne programy dydaktyczne. In Infotech 2007 modern information and communication technology in education. Olomouc : Votobia, 2007. s. 451 - 456. ISBN 978-80-7220-301-7. Dostupné na http://infotech.upol.cz/web sbornik/sbornik_INFOTECH07_dil_1.pdf.

(17) MAYER. R. E. - MORENO, R. Animation as an Aid to Multimedia Learning. Educational Psychology Review. Volume 14, Number 1 / March, 2002. p. 87 - 99. ISSN 1040-726X (Print). ISSN 1573-336X (Online).

(18) PARLANGELI O. - MARCHIGIANI, E. BAGNARA, S. Multimedia systems in distance education: effects of usability on leasing. Interacting with Computers. Volume 12, Issue 1, September 1999, p. 37 - 49. ISSN 0953-5438.

(19) eBooks.com : The digital bookstore [online]. Citováno dne 18. 1. 2009. Dostupné na http://www.ebooks.com.

(20) eLibrary [on-line]. Citováno dne 18. 1. 2009. Dostupné na http://e-library.net.

(21) Free - ebooks.net [on-line]. Citováno dne 18. 1. 2009. Dostupné na http://www.freeebooks.net.
(22) Google : vyhledávání knih [on-line]. Citováno dne 18. 1. 2009. Dostupné na http://books.google.com.

(23) PRŮCHA, J. Učebnice: teorie a analýzy edukačního média : príručka pro studenty, učitele, autory a výzkumné pracovníky. Brno : Paido, 1998. 148 s. ISBN 80-85931-49-4.

(24) KOBÍKOVÁ, Z. Hypertext. Revue pro média. Citováno dne 18. 1. 2009. Dostupné na http://fss.muni.cz/rpm/Revue/Heslar/hypertext.htm. (25) BERTRAND, Y. Soudobé teorie vzdélávání. Praha : Portál, 1998. 247 s. ISBN: 80-7178-216-5.

(26) DÖMISCHOVÁ, I. PowerPoint jako součást výuky cizích jazyků na vysoké škole. In Vysokoškolský pedagog: člověk nebo počítač? Olomouc : MVŠO, 2007. s. 63 - 67. ISBN 97880-87240-00-7.

(27) BABIĆ, N. - IROVIĆ, S. Educational Potentials of PowerPoint. In Technika informatyka - edukacja. Rzeszow : Uniwersytet Rzeszowski, 2007. s. 95 - 100. ISBN 978-83-88845-91-8.

(28) TVARŮŽKA, V. Výukový klip a jeho využití při expozici pojmových map a konceptuálních znalostí. In Trendy ve vzdélávání. Olomouc : VOTOBIA, 2008. s. 251 - 254. ISBN 978-80-7220-311-6.

(29) AZEVEDO, R. - JACOBSON, M. J. Advances in scaffolding learning with hypertext and hypermedia: a summary and critical analysis. Educational Technology Research and Development. Springer Boston, Volume 56, Number 1 / February, 2008. p. 93 - 100. ISSN 1042-1629 (Print). ISSN 1556-6501 (Online).

(30) JOACHIM P. Hasebrook Learning with multimedia and hypermedia: Promises and Pitfalls Citováno dne 18. 1. 2009. Dostupné na http://www.uni-oldenburg.de/zef/cde/media/ readings/apahyper.pdf

(31) HOFSTETTER, F. T. - FOX, P. Multimedia Literacy. New York : McGrawHill, 1995. 360 p. ISBN 0079119565.

(32) HOFSTETTER, F. T. Internet Literacy. New York, McGraw-Hill Irwin, 2001. 354 p. ISBN 0072398213.

Jiří Dostál, PaedDr. PhDr. Ph.D.

Katedra technické a informační výchovy

Pedagogická fakulta UP

Žižkovo nám. 5

77140 Olomouc

Česká republika

Telefon: +420 739249125

E-mail: j.dostal@upol.cz 